\title{
PERLINDUNGAN HUKUM PERAWAT PRAKTIK ATAS TINDAKAN PELAYANAN GAWAT DAN DARURAT PADA MASYARAKAT PEDESAAN DI DESA SUSUKAN KABUPATEN SEMARANG
}

\author{
Oleh : \\ Indra Yuliawan, Adhi Budi Susilo \\ Fakutas Hukum Universitas Ngudi Waluyo \\ indra.yuliawan@yahoo.com,adhi_budi@gmail.com
}

\begin{abstract}
ABSTRAK
Tenaga kesehatan banyak mendapatkan sorotan dari masyarakat, karena kesehatan merupakan kebutuhan pokok manusia dan kualitas sumber daya manusia (SDM) ditentukan dua faktor yang saling berhubungan yakni pendidikan dan kesehatan. Kesehatan merupakan prasyarat utama agar upaya pendidikan berhasil, sebaliknya pendidikan yang diperoleh akan sangat mendukung tercapainya peningkatan status kesehatan seseorang. Sorotan masyarakat terhadap profesi tenaga kesehatan merupakan suatu kewajaran karena pelayanan kesehatan merupakan kebutuhan yang tidak bisa ditunda dan diabaikan. Profesionalitas profesi kesehatan menjadi harga mati yang tidak boleh ditawar oleh siapapun, karena berhubungan dengan kebutuhan pokok manusia. Tenaga kesehatan terutama perawat dan bidan sebagai profesi mempunyai tanggung jawab pokok pelayanan kesehatan. Perawat dan bidan bertanggung jawab dalam bidang kesehatan secara preventif dan harus mampu menangani berbagai macam pelayanan kesehatan bahkan pelayanan yang memerlukan tindakan darurat, dan melakukan rujukan yang cepat dan tepat. Sebagai Subjek hukum keperanan perawat wajib dilindungi secara hukum. Perlindungan tersebut diperlukan manakala penanganan pertama yang dilakukan perawat dan bidan tidak dapat menyelamat nyawa seseorang dan kemudian ada kekecewaan dalam diri keluarga sang pasien terhadap tindakan bidan atau perawat tersebut. Perawat yang mempunyai latar belakang ilmu kesehatan menjadi tujuan masyarakat bilamana ada anggota masyarakat sedang sakit, terlebih lagi jika tidak ada dokter di sekitarnya. Dalam kondisi seseorang sakit tentunya perawat tidak dapat menolak untuk membantu menyembuhkan bahkan menyelamatkan terlebih lagi dalam kondisi gawat bahkan darurat.

Kata Kunci : Perawat, Perlindungan Hukum.
\end{abstract}

\section{Abstraction}

Health workers get a lot of attention from the public, because health is a basic human need and the quality of human resources (HR) determined two interrelated factors of education and health. Health is a major prerequisite for educational efforts to succeed, otherwise education will greatly support the achievement of improving one's health status. The public's spotlight on the health professional profession is a fairness because health care is a necessity that can not be postponed and ignored. Professionalism of the health profession becomes a fixed price that no one can bargain for, because it deals with human needs. Health workers, especially nurses and midwives as professions have primary responsibility for health services. Nurses and midwives are in charge of health in a preventive manner and should be able to handle a wide range of health services and even services that require emergency measures, and make quick and precise referrals. As the subject of nurses' law of nurses shall be protected by law. Such protection is necessary when the first handling of the nurse and midwife can not save a person's life and then there is disappointment in the patient's family for the actions of the midwife or nurse. Nurses who have a health science background become a community goal when there are members of the community are sick, especially if there is no doctor around. In the condition 
of someone sick of course nurses can not refuse to help heal even rescue even more in emergency conditions even emergency.

Keywords: Nurse; Legal Protection;

\section{PENDAHULUAN}

Perkembangan kehidupan dalam masyarakat dewasa ini telah mempengaruhi pola berpikir masyarakat. Hal ini tidak terjadi di masyarakat perkotaan saja akan tetapi juga masyarakat pedesaan. Masyarakat pedesaan sudah sadar akan hal-hal yang berhubungan pilar kehidupan yang penting salah satunya yaitu kesehatan. Kesehatan merupakan hal terpenting dalam kehidupan manusia bahkan setiap hari setiap manusia akan selalu bersinggungan dengan kesehatan.

Hukum mempunyai fungsi sebagai pengatur dan pelindung manusia sekaligus sebagai upaya pemenuhan kepentingan manusia. Pelaksanaan hukum harus dapat berlangsung secara normal damai dan tertib. Dalam pelaksanaannya hukum seringkali dilanggar, sehingga pelanggaran terhadap hukum diselesaikan melalui penegakan hukum, sedangkan dalam penyelesaiaan pelanggaran hukum diperlukan perlindungan hukum.

Perlindungan Hukum sebagai perlindungan akan harkat dan martabat, serta pengakuan terhadap hak-hak asasi manusia yang dimiliki oleh subyek hukum berdasarkan ketentuan hukum dari kesewenangan. Dan perlindungan hukum bagi rakyat terdiri dari perlindungan hukum preventif dan perlindungan hukum represif. (Philipus M Hadjon, 1997)

Perlindungan hukum preventif adalah perlindungan hukum ini bertujuan untuk mencegah terjadinya sengketa. Sehingga upaya yang dilakukan lebih difokuskan untuk meminimalisir terjadinya masalah yang sekaligus untuk menghindari munculnya akibat dari suatu masalah. Sedangkan perlindungan hukum repsresif adalah perlindungan yang bertujuan untuk menyelesaikan permasalahan atau sengketa yang timbul. Perlindungan ini baru akan dilakukan pada saat pelaksanaan perjanjian berlangsung. Dengan demikian perlindungan yang diberikan lebih ditekankan pada upaya untuk mencari penyelesaian sengketa dalam rangka mempertahankan hak-hak yang dimiliki para pihak.(Setiono, 2004)

Sedangkan perlindungan preventif diwujudkan dengan adanya peraturan perundang-undangan yang bersifat regulatif. Aturan hukum baik berupa Undang-Undang maupun hukum tidak tertulis, dengan demikian, berisi aturan-aturan yang bersifat umum yang menjadi pedoman bagi individu bertingkah laku dalam hidup bermasyarakat, baik dalam hubungan dengan sesama maupun dalam hubungannya dengan masyarakat. Aturan-aturan itu menjadi batasan bagi masyarakat dalam membebani atau melakukan tindakan terhadap individu. Adanya aturan semacam itu dan pelaksanaan 
aturan tersebut menimbulkan kepastian hukum. Dengan demikian, kepastian hukum mengandung dua pengertian yaitu (Peter Mahmud, 2008):

1. Adanya aturan yang bersifat umum membuat individu mengetahui perbuatan apa yang boleh atau tidak boleh dilakukan;

2. Berupa keamanan hukum bagi individu dari kesewenangan pemerintah karena dengan adanya aturan yang bersifat umum itu individu dapat mengetahui apa saja yang boleh dibebankan atau dilakukan oleh negara terhadap individu.

Berdasarkan Undang-Undang No.38 Tahun 2014 tentang keperawatan, dalam pasal 29 ayat 1 menyebutkan bahwa dalam menyelenggarakan praktek keperawatan, perawat bertugas sebagai :
a. Pemberi Asuhan Keperawatan
b. Penyuluh dan konselor bagi Klien
c. Pengelola Pelayanan Keperawatan
d. Peneliti Keperawatan
e. Pelaksana tugas berdasarkan pelimpahan wewenang dan atau
f. Pelaksana tugas dlam keadaan keterbatasan tertentu.

Bahwa dari tugas perawat diatas, jelas praktek keperawatan pelayanan yang berbentuk asuhan keperawatan. Sejalan dengan tugas keperawatan ternyata terdapat pengecualian. Perawat tidak berbentuk asuhan akan juga dapat berbentuk tindakan medis yaitu manakala perawat mendapat pelimpahan wewenang secara delegatif atau mandat (huruf f) sehingga tindakan medis tersebut sudah tentu atas izin dan sepengetahuan dokter dan disertai pelimpahan tanggung jawab. Hal ini membuat perawat harus ekstra hati-hati dalam melakukan tindakan medis. Bahwa perawat juga dapat melakukan tindakan medis bilamana dalam keadaan keterbatasan tertentu yang merupakan penugasan pemerintah yang dilaksanakan pada keadaan tidak ada tenaga medis dan atau tenaga kefarmasian. Dalam pasal 33 ayat 4 yang menyatakan : Dalam melaksanakan tugas pada keadaan keterbatasan tertentu sebagaimana dimaksud pada ayat 1 , Perawat berwenang :

a. Melakukan pengobatan untuk penyakit umum dalam hal tidak terdapat tenaga medis.

b. Merujuk pasien sesuai dengan ketentuan pada sistem rujukan;

c. Melakukan pelayanan kefarmasian secara terbatas dalam hal tidak terdapat tenaga kefarmasian.

Fungsi perawat sebagai tenaga medis untuk melakukan tindakan medis hanya terbatas pada penyakit umum saja. Terhadap penyakit khusus tetap dirujuk. Keterkaitan dengan tindakan yang 
bersifat emergency/darurat ternyata Perawat diberikan kewenangan oleh Undang-Undang untuk memberikan pertolongan yakni perawat dapat melakukan tindakan medis dan pemberian obat sesuai dengan kompetensinya. Tindakan medis tersebut bertujuan untuk menyelamatkan nyawa atau keadaan mengancam nyawa sesuai dengan hasil evaluasi berdasarkan keilmuwannya ( pasal 35 UndangUndang No. 38 tahun 2014 tentang keperawatan), akan tetapi terhadap hal ini masih diatur oleh Peraturan Menteri. Selaras dengan hal tersebut diatas jelas dalam hal perawat melakukan tindakan emergency atau darurat perlu adanya perlindungan hukum karena pada hakekatnya praktek keperawatan berbentuk asuhan.

\section{METODOLOGI PENELITIAN}

Sumber Data Primer Penelitian ini menggunakan metode pendekatan yuridis, dengan data sekunder melalui studi kepustakaan perlindungan hukum bagi perawat. Peneliti menggunakan spesifikasi penelitian secara diskriptif analitis artinya penulis menggambarkan ruang lingkup batasanbatasan yang tegas mengenai Pengaturan penyelenggaraan praktek perawat serta perlindungan hukum bagi penyelenggaraan tindakan medis dalam kondisi gawat dan darurat yang dilakukan baik bidan maupun perawat. setelah data diperoleh dilakukan analisis diskriftif atau secara kualitatif. Penelitian ini dilakukan terhadap responden perawat yang bekerja di Puskesmas Kecamatan Susukan Kabupaten Semarang, Perawat yang praktek di Kecamatan Susukan Kabupaten Semarang dan wawancara kepada PPNI (Persatuan Perawat Nasional Indonesia) Kabupaten Semarang. Penelitian deskripsi analitis merupakan suatu penelitian yang berusaha menggambarkan masalah hukum, sistem hukum, dan mengkajinya atau menganalisisnya sesuai dengan kebutuhan dari penelitian yang bersangkutan.(Hafidz,2009)

\section{HASIL PENELITIAN DAN PEMBAHASAN}

Penelitian ini dilakukan di Wilayah Kecamatan Susukan Kabupaten Ungaran dan di Kantor Persatuan Perawat Nasional Indonesia Kabupaten Semarang). Alasan mengapa dipilih kecamatan Susukan dikarenakan letak wilayahnya termasuk jauh dari pusat Kota Kabupaten Semarang, dan merupakan kecamatan yang berbatasan dengan Kabupaten Boyolali.

Di Kecamatan Susukan khususnya berada di Pusat Kesehatan Masyarakat Kecamatan Susukan, sebagai responden yaitu terdapat 3 (tiga) orang perawat dan 5 (lima) orang penduduk di Kecamatan Susukan Kabupaten Ungaran. Sedangkan di Kantor Persatuan Perawat Nasional Indonesia (PPNI) telah dilakukan wawancara terhadap Legal Departemen PPNI Kabupaten Semarang. 
Bahwa cakupan penelitian ini adalah perawat praktek yang berada di masyarakat. Dalam UndangUndang no.38 tahun 2014 tentang Keperawatan mengenai praktek keperawatan dibagi menjadi 2 (dua) yakni :

1. Praktik Keperawatan mandiri.

2. Praktik Keperawatan di Fasilitas Pelayanan Kesehatan.

Peneliti melakukan penelitian terhadap Praktik Keperawatan mandiri.

Dari hasil penelitian dapat disajikan hasil penelitian sebagai berikut :

A. Perawat.

Penelitian ini meneliti Perlindungan Hukum terhadap Perawat yang melakukan tindakan Gawat Darurat di masyarakat Pedesaan Susukan. Di dalam masyarakat wilayah Kecamatan Susukan yang di jadikan sampel pada saat masyarakat tersebut berada di Puskesmas Kecamatan Susukan dan di Kantor Kecamatan Susukan yang menjelaskan bahwa kebanyakan masyarakat bilamana ada anggota masyarakat yang sakit seperti demam tinggi, kejang-kejang, pertolongan pertama akan ke Bidan, akan tetapi di Kecamatan Susukan ini karena belum ada perawat praktek maka kebanyakan pertolongannya kepada Bidan. Oleh Bidan pun hanya di cek keadaan pada umumnya kemudian disarankan untuk segera di bawa ke Rumah Sakit terdekat yaitu di Kota Salatiga dan di Kabupaten Boyolali.

Berdasarkan penelitian di lapangan diperoleh data informasi bahwa di wilayah Kecamatan Susukan Kabupaten Semarang belum ada Perawat Praktek Mandiri. Hal ini disebabkan Perawat belum paham mengenai peraturan tentang Perawat Praktek Mandiri. Padahal peran dan keberadaan Perawat Praktek di masyarakat sangat penting sebagai bentuk kepedulian Perawat dalam membantu masyarakat untuk tujuan kehidupan masyarakat. Berikut di bawah ini adalah merupakan hasil survey peneliti terkait dengan penelitian yang dibuat :

a. Sebagai seorang profesional sangat penting tentang pemahamanan dan pengetahuan peraturan terkait dengan keperawatan karena hal ini mempengaruhi kinerja perawat di masyarakat. Terlebih lagi masyarakat khususnya di pedesaan menganggap Perawat itu dapat menolong orang sakit seperti halnya dokter dan bidan.

b. Selaras dengan hasil survey juga memperoleh hasil bahwa Perawat belum paham mengenai regulasi atau peraturan-peraturan dengan sejelas-jelasnya dari instansi yang terkait atau pun dari PPNI tentang pelaksanaan hak dan kewajiban perawat ketika berada di masyarakat. Dengan kata lain perawat merasa dirinya masih "kategori abu abu". Pengertian kategori abuabu ini dimaksudkan adalah perawat masih ragu bilamana ikut andil secara aktif di masyarakat sebagai perawat praktek mandiri dalam upaya pelayanan kesehatan di masyarakat itu perawat apakah ada perlindungannya atau tidak. Bahwa perawat dalam melaksanakan 
tugasnya harus taat dengan aturan-aturan yang berlaku, akan tetapi perawat dihadapkan dalam kenyataan harus menolong orang sakit karena masyarakat mengetahui perawat tersebut dapat menolong orang yang sakit.

c. Berdasarkan interview dengan perawat di Puskesmas Susukan diperoleh fakta bahwa masyarakat di pedesaan menganggap Perawat dan juga Bidan menjadi tempat tujuan untuk dapat memberikan pertolongan jika ada anggota masyarakat yang sakit dalam hal ini khususnya sakit gawat dan darurat. Berdasarkan Undang-Undang No.44 tahun 2009 tentang Rumah Sakit pada pasal 1 huruf 2 yang disebut sebagai gawat darurat ialah keadaan klinis pasien yang membutuhkan tindakan medis segera guna penyelamatan nyawa dan pencegahan kecacatan lebih lanjut. Darurat medis adalah suatu kondisi dalam pandangan penderita keluarga atau siapapun yang bertanggung jawab dalam membawa penderita ke rumah sakit memerlukan pelayanan medis segera.

d. Dalam penelitian ini diperoleh fakta bahwa Perawat ketika berada di masyarakat selalu terbuka dan siap jika ada anggota masyarakat yang membutuhkan pertolongan atas sakit gawat dan darurat. Perawat siap melakukan pertolongan pertama sampai mengantarkan ke Puskesmas dan Rumah Sakit terdekat. Misal ada anggota masyarakat yang kecelakaan, perawat memberikan pertolongan pertama dengan membalut luka untuk mengurangi pendarahan, atau memberikan pertolongan agar luka patah tulang tidak semakin parah dengan cara sederhana menggunakan papan kemudian dibalut dengan kain dan pertolongan lain-lain.

e. Menurut perawat yang kami survey sebenarnya mereka ingin melakukan pertolongan yang lebih misal menjahit luka dll, akan tetapi perawat tidak siap dengan peralatan khusus tersebut. Contoh sakit gawat darurat yang sering ditemui perawat yakni demam tinggi pada anak. Dalam hal ini yang dilakukan perawat yaitu pertolongan pertama dengan memberikan kompres atau tidak perlu menunggu lama dapat segera diantarkan ke Rumah Sakit terdekat.

f. Menurut Perawat dalam survey ini, masyarakat sekarang ini khususnya di wilayah Kabupaten Semarang sudah lebih paham dan sadar akan kesehatan dan pencegahan sakit karena :

- Masyarakat Desa akhir ini telah teredukasi tentang kesehatan tentang alat-alat komunikasi terutama penduduk pada usia muda maka bila ada anggota keluarga sakit mereka segera menuju tenaga kesehatan yaitu bidan, hal mana karena komunitas bidan yang praktek sudah banyak sehingga masyarakat cenderung mengenal bidan yang sudah lama lebih dulu aktif di masyarakat.

- Sarana transportasi di Desa yakni pembangunan akses jalan di dalam desa atau antar desa sudah lebih baik. Terkait dengan sudah adanya bidan praktek di desa maka jika ada orang sakit relatif sudah dapat terjangkau yakni sekitar kurang lebih 10 menit dalam satu desa sehingga setidak-tidaknya setiap anggota masyarakat sudah tertangani. 
- Setiap masyarakat terdapat kultur atau budaya yang khas dan kultur tersebut turun temurun akan selalu dilakukan oleh masyarakat tersebut, hal ini membuat suatu kebiasaan yang berlaku di kehidupan masyarakat itu. Perawat sebagai seorang yang hidup di tengah masyarakat juga harus masuk ke dalam kebiasaaan itu. Dalam teori Ilmu Hukum, Kebiasaan merupakan perbuatan menurut garis tingkah laku yang tetap (habitual). Perbuatan itu harus dilakukan secara tetap. Kebiasaan dapat berupa tingkah laku atau perbuatan dan pola fikir. Dalam hal berupa perbuatan dapat berupa perbuatan manusia mengenai hal-hal tertentu yang dilakukan berulang-ulang. Sedangkan dalam pola fikir cenderung kepada elemen psikologis artinya adanya keyakinan pada masyarakat bahwa perbuatan itu harus dilakukan karena telah merupakan suatu kewajiban. Masyarakat sudah tertata dalam pola berfikir dan perbuatannya bilamana salah satu anggota masyarakat ada yang sakit atau terkena penyakit, mereka pergi menuju orang yang dianggap dapat menyembuhkan penyakit atau sakit yang dideritanya. In cassu cara berpikir dimasyarakat dan perbuatan yang demikian tidak dapat dihindari oleh seorang perawat. Perawat mempunyai keinginan kuat untuk menolong dan membantu anggota masyarakat yang sedang membutuhkan. Merupakan hal yang diluar kebiasaan apabila seorang Perawat hanya diam saja melihat ada anggota masyarakat yang sedang sakit tidak melakukan pertolongan dll. Berdasarkan wawancara dengan beberapa perawat yang sedang bertugas di Puskesmas Susukan berpendapat bahwa Perawat ketika di masyarakat dituntut untuk menolong orang sakit, bilamana tidak maka orang akan menganggap sebagai hal yang tidak wajar dan lebih parah lagi perawat tersebut akan dikucilkan dari pergaulan masyarakat. Peran perawat yang begitu besar ketika berada di masyarakat sehingga setiap perawat harus mempunyai jiwa kemanusiaan yang besar, akan tetapi Jiwa Kemanusiaan ini Jiwa kemanusiaan dari Perawat yang sudah tertanam dalam sanubari tidak cepat luntur. Perawat hanya terbentur dengan sikap keragu-raguan akibat belum maksimalnya dalam pengetahuan tentang peraturan perundang-undangan.

g. Ada perawat yang tetap berpegang teguh dengan jiwa kemanusiaannya, Perawat tersebut tetap menjalankan profesi bilamana sedang berada di tengah masyarakat. Mereka sangat mau Perawat yang hidup di masyarakat harus berperan aktif dalam penegakan kesehatan di lingkungannya. Beliau berpendapat bahwa hidup harus berguna bagi masyarakat sekitar. Apalagi ditakdirkan sebagai seorang Perawat. Perawat tidak hanya bisa bekerja di Rumah Sakit atau Pusat Pelayanan Kesehatan, juga ketika berada di tengah masyarakat pun dapat bekerja. Menjadi Perawat Praktek Mandiri menurut beliau mempunyai resiko yang cukup tinggi sehingga banyak Perawat yang tidak memilihnya. Di dalam Undang Undang 38 tahun 2014 tentang Keperawatan dijelaskan bahwa dalam Pasal 29 ayat 1 menyatakan "Dalam menyelenggarakan Praktik Keperawatan, Perawat bertugas sebagai (e) pelaksana tugas 
berdasarkan pelimpahan wewenang". Dalam pasal 31 ayat 1 menyatakan "Pelaksanaan tugas berdasarkan pelimpahan wewenang sebagaimana dimaksud dalam Pasal 29 ayat (1) huruf e hanya dapat diberikan secara tertulis oleh tenaga medis kepada Perawat untuk melakukan sesuatu tindakan medis dan melakukan evaluasi pelaksanaannya".

h. In cassu Perawat yang kami survey tersebut melakukan kerjasama dengan dokter di Kecamatan Susukan. Dokter tetap bertanggungjawab terhadap pekerjaannya hanya saja dalam pekerjaannya dibantu oleh Perawat. Dan jika dokter berhalangan maka Perawat berperan aktif dalam pelayanan medis di tempat praktek dokter tersebut dengan tetap berkonsultasi kepada dokter dalam pelayanannya kepada masyarakat. Hal ini lah yang disebut sebagai pelimpahan wewenang secara mandat, selaras dengan pasal 32 ayat (5) Undang-Undang No.38 tahun 2014 yang menyatakan "Pelimpahan wewenang secara mandat diberikan tenaga medis kepada Perawat untuk melakukan sesuatu tindakan medis di bawah pengawasan".

Masih di pasal 32 dalam ayat (6) yang menyatakan "tanggung jawab atas tindakan medis pada pelimpahan wewenang mandat sebagaimana dimaksud pada ayat (5) berada pada pemberi pelimpahan wewenang. Selanjutnya dalam ayat (7) dinyatakan bahwa "Dalam melaksanakan tugas berdasarkan pelimpahan wewenang sebagaiamana dimaksud pada ayat (1), perawat berwenang :

a. Melakukan tindakan medis yang sesuai dengan kompetensinya atas pelimpahan wewenang delegatif tenaga medis.

b. Melakukan tindakan medis di bawah pengawasan atas pelimpahan wewenang mandat dan

c. Memberikan pelayanan kesehatan sesuai dengan program Pemerintah.

Menurutnya praktek keperawatan menggunakan pelimpahan wewenang mandat sudah tepat karena di satu sisi pengalaman dan pengetahuan perawat bertambah dan juga dapat menunjukkan eksistensi perawat itu dimasyarakat sekitar.

Perawat juga menyadari dan mengetahui masyarakat disekitarnya sudah pasti akan menganggap perawat dapat mengatasi permasalahan kesehatan sehingga jika Perawat tersebut tidak aktif maka masyarakat akan meng-'hukum' perawat tersebut misalnya dikucilkan di masyarakat.

B. Masyarakat

Dari hasil penelitian berupa wawancara dengan anggota masyarakat yaitu yang berasal dari Desa Koripan, Desa Susukan dan Desa Bulu/Galangan menyatakan bahwa jika ada anggota keluarga yang sakit, tempat pertama yang akan dituju yaitu bidan, hal mana karena bidan lebih memasyarakat. Dari hasil survey masyarakat juga mengetahuinya adanya bidan yang praktek, sedangkan Perawat praktek belum mengetahui. Masyarakat di Desa saat ini sudah tercakupi dengan adanya Bidan yang praktek dan puskesmas, akan tetapi apabila ada Perawat Praktek itu akan semakin baik cakupan penanganan 
masalah kesehatan di masyarakat khususnya pedesaan. Masyarakat pedesaan khususnya di Kecamatan Susukan juga sangat senang bilamana adanya penyuluhan kesehatan oleh Perawat, karena akan semakin menambah wawasan dan pengetahuan tentang penyakit dan bagaimana cara menanggulangi suatu penyakit. Perkembangan teknologi informasi yang sedemikian pesat sampai mencakup ke pelosok pedesaan di Kabupaten Semarang ini khususnya Kecamatan Susukan, juga menjadi salah satu pembantu masyarakat dalam mengetahui perkembangan dan penanggulangan penyakit.

Perkembangan pembangunan di desa juga sudah lebih bagus dari tahun ke tahun. Pemerintah dengan program percepatan pembangunan desa sudah dapat dirasakan oleh Masyarakat. Masyarakat pedesaan sudah terbantu dengan pembangunan jalan dan jembatan sehingga memudahkan masyarakat yang akan meminta pertolongan kesehatan. Menurut masyarakat yang menjadi kendala jika ada sakit gawat darurat di pelosok desa, yakni belum ada pelayan medis yang cepat. Hal mana karena dokter pun sangat jarang yang bisa dihubungi cepat. Tenaga Medis yang paling dekat adalah Bidan yang sudah lebih dulu dikenal oleh masyarakat. Masyarakat berharap posisi Perawat juga seperti Bidan yang dekat dengan lingkungan.

Undang-Undang Keperawatan (UUK) merupakan dasar hukum praktek keperawatan. Isi Undang-Undang Keperawatan harus diketahui oleh profesi dan calon profesi (mahasiswa). Hal ini dikarenakan, tidak hanya profesi perawat yang membutuhkan Undang-Undang ini tetapi calon profesi perawat juga harus mengetahui isi dari Undang Undang Keperawatan agar di masa mendatang bisa menjadi perawat yang taat akan aturan serta menjalankan hak dan kewajibannya sebagai seorang perawat.

Menjadi seorang perawat tentunya harus memahami dan melakukan praktek keperawatan dengan baik dan benar. Hal tersebut untuk menjadikan perawat yang profesionalisme. Praktik Keperawatan ini dapat dilaksanakan pada fasilias pelayanan kesehatan dan tempat lainnya sesuai dengan kondisi kliennya. Pada akhirnya praktek keperawatan harus fleksible, karena dalam rangka memberikan pelayanan kesehatan yang maksimal. Dimanapun keberadaan Perawat harus menjunjung tinggi aturan hukum tentang keperawatan.

\section{Persatuan Perawat Nasional Indonesia}

Persatuan Perawat Nasional Indonesia atau yang disingkat PPNI sebagai wadah/organisasi profesi tunggal yang mengatur segala tindakan perawat dan mengetahui pemetaan perawat sekaligus juga berperan sebagai pelindung bagi perawat yang menjalankan tugas profesinya termasuk dalam konteks menjamin kepastian hukum. Peran PPNI sangat besar dalam menentukan profesionalitas seorang Perawat. Berdasarkan Undang-Undang Kesehatan PPNI mempunyai peran bertanggung jawab pada standar kompetensi, standar etik, dan standar profesi sehingga dalam perlindungannya PPNI dapat memberikan kepastian hukum berdasarkan standar standar tersebut. Kepastian Hukum 
dalam Ilmu Hukum lebih merupakan kepastian peraturan perundang-undangan, dalam pengertian secara normatif peraturan perundang-undangan tersebut mengatur bagaimana seseorang bertindak atau perbuatan manusia itu telah melanggar peraturan perundang-undangan sehingga berdasarkan peraturan tersebut seseorang dikenakan sanksi atas perbuatannya. Kepastian hukum inilah yang mempunyai peranan penting sehingga merupakan tujuan hukum yang pastinya untuk ketertiban masyarakat.

Berdasarkan Undang-Undang Kesehatan standar profesi dan standar etik dibuat oleh Organisasi Profesi karena :

a. Organisasi Profesi harus mengetahui penyebaran perawat dalam praktek, yaitu apapun yang dilakukan perawat dalam melaksanakan tugas kliennya melalui pendekatan asuhan keperawatan bio sosio kultural dan spiritual termasuk kognitif misalnya masyarakat sakit akibat tidak tahu kandungan gizi makanan yang dimakannya maka perawat dapat menjelaskan terkait makanan tersebut.

b. Memberikan pengetahuan kepada perawat melakukan praktek baik di Rumah Sakit, Puskesmas, Klinik atau fasilitas pelayanan kesehatannya lainnya dan praktek mandiri bahwa konteksnya perawat adalah asuhan bukan pengobatan. Perawat hanya diperbolehkan memberikan obat berlogo hijau dan logo biru.

Dalam Undang-Undang Keperawatan telah mengatur cara atau petunjuk bagi Perawat untuk dapat bertindak dan berinteraksi dengan masyarakat sekitarnya. Dengan telah diundangkanya UndangUndang Keperawatan telah diberikan ruang lingkup bagi perawat dalam melakukan pekerjaanya.

Dalam Kegawat daruratan perawat boleh melakukan praktek pelayanan masyarakat di luar kewenangannya untuk desa-desa daerah tertentu yang dimana daerah tersebut tidak ada tenaga kesehatan lainnya. Dalam hal ini harus ada Surat Keterangan dari Pemerintah Kabupaten setempat.

Selain itu ada hal yang perlu diperhatikan dalam Undang-Undang Keperawatan ini salah satunya perawat sebagai pelimpahan wewenang. Pelimpahan wewenang yang dimaksud dilakukan secara delegatif disertai dengan pelimpahan tanggung jawab. Pelimpahan wewenang yang diberikan hanya dapat diberikan kepada perawat profesi dan/atau perawat vokasi yang sudah terlatih dan telah terlatih untuk melakukan tindakan medis dibawah pengawasan, sehingga tak sembarangan perawat dapat diberkan pelimpahan wewenang demi menjamin keselamatan klien. Hal ini sesuai dengan pasal 32 ayat 3-6 yaitu

- Pelimpahan wewenang secara delegatif untuk melakukan sesuatu tindakan medis diberikan oleh tenaga medis kepada perawat dengan disertai pelimpahan tanggung jawab. 
- Pelimpahan wewenang secara delegatif sebagaimana dimaksud pada ayat (3) hanya dapat diberikan kepada perawat profesi atau perawat terlatih yang memiliki kompetensi yang diperlukan.

- Pelimpahan wewenang secara mandat diberikan oleh tenaga medis kepada Perawat untuk melakukan sesuatu tindakan medis di bawah pengawasan.

- Tanggung jawab atas tindakan medis pada pelimpahan wewenang mandat sebagaimana dimaksud pada ayat (5) berada pada pemberi pelimpahan wewenang.

Salah satu hal yang saat ini banyak diperbicarakan yaitu tentang pelaksanaan tugas dalam keterbatasan tertentu khususnya dalam keadaan tidak ada tenaga medis dan/atau tenaga kefarmasian. Hal ini telah diatur pada Undang-Undang Keperawatan pasal 33. Dengan adanya aturan tentang hal ini, maka perawat mendapat perlindungan khususnya dalam pemberian tindakan disaat tidak ada tenaga medis dan/atau tenaga kefarmasian ditempat sedangkan klien membutuhkan suatu tindakan yang cepat. Jika keadaan tersebut terjadi, perawat dapat memberikan tindakan kepada klien. Hal ini sesuai dengan pasal 33 ayat 2-4. Dalam tindakan medis yang bersifat delegasi yaitu sifatnya atributif dan mandiri mengacu kepada prinsip asuhan. Kewenangan pendelegasian merupakan kewenangan yang didapatkan delegasi

Undang-Undang Keperawatan sebenarnya telah melindungi dunia kerja Keperawatan. Baik praktek di Fasilitas kesehatan maupun praktek di masyarakat secara tertulis hubungan kerja antara pasien dengan perawat dalam Undang-Undang Keperawatan termasuk dalam jenis perjanjian Inspanningsverbintenis. Yaitu perjanjian yang mendasarkan kepada usaha para pihak yang maksimal, artinya perjanjian upaya yakni kedua belah pihak berjanji atau sepakat untuk berdaya upaya secara maksimal guna mewujudkan apa yang diperjanjikan.

Bahwa dalam Hukum Perjanjian mengenal 2 (dua) jenis perjanjian yaitu :

1. Perjanjian Resultaatsverbintenis, yaitu perjanjian yang akan memberikan resultaat atau hasil yang nyata sesuai dengan apa yang diperjanjikan.

2. Perjanjian Inspanningsverbintenis, yaitu perjanjian yang mendasarkan kepada usaha para pihak secara maksimal. Jadi di sini tidak mengutamakan hasil yang didapat akan tetapi mengutamakan pekerjaan yang sudah dilakukan secara maksimal sesuai dengan Standar Operasional Pekerjaan yang dilakukan oleh pihak yang berkompeten.

Bahwa selaras dengan hal diatas Pelayanan medis terhadap pasien oleh Perawat itu masuk dalam perjanjian Inspanningsverbintenis, yakni perjanjian antara pasien dengan perawat untuk melakukan pelayanan kesehatan dengan dasar mengutamakan pekerjaan yang maksimal. Disini haruslah dilihat dulu apakah Perawat melakukan kerja maksimal dalam pelayanan kesehatan sesuai dengan wewenangnya yang telah diatur oleh Undang-Undang. Tuntutan terhadap keberhasilan oleh pasien 
tidak boleh dikenakan kepada perawat. Untuk itulah terkait dengan kesembuhan, sesuai dengan bentuk penanganannya, seorang perawat tidak dapat menjanjikan kesembuhan kepada pasien bahkan seorang dokter pun tidak diperbolehkan. Selaras dengan hal tersebut tidaklah menjadi seorang perawat tidak dapat dituntut atau diperkarakan akan tetapi sesuai dengan prinsip Inspanningsverbintenis, maka yang menuduhlah yang harus diberikan beban pembuktian.

Sehubungan dengan bentuk perlindungan yang diberikan oleh organisasi, maka menurut PPNI Kabupaten Semarang, bentuk yaitu berupa pendampingan kepada Perawat dengan terus mengutamakan mediasi dengan Pengadu atau Pelapor.

Mediasi berdasarkan Undang-Undang No.36 tahun 2009 tentang kesehatan dimuat dalam pasal 29 yaitu dalam hal tenaga kesehatan diduga melakukan kelalaian dalam menjalankan profesinya, kelalaian dalam menjalankan profesinya, kelalaian tersebut harus diselesaikan terlebih dahulu melalui mediasi.

Mediasi disini ditekankan karena sifat pelayanan kesehatan adalah terkait dengan hati nurani dan keyakinan dari perawat itu sendiri, Jikalau perawat berkerja sudah sesuai dengan SOP dan dengan hati nurani iklas menolong akan tetapi hasilnya tidak memuaskan klien/pasien maka itulah fungsi mediasi agar permasalahan dapat dimusyawarahkan tanpa mengurangi hak-hak para pihak. Pelayanan kesehatan kuncinya adalah tingkat kepatuhan terhadap aturan peraturan yang berlaku. Pendampingan yang dimaksud juga termasuk pembelaan yang dibantu dilakukan oleh Advokat. Hal yang terpenting digaris bawahi yaitu perlindungan diberikan oleh organisasi manakala Perawat yang bersangkutan dalam melakukan penanganan kepada klien/pasien sudah sesuai dengan peraturan perundangundangan, standart pelayanan, dan standar asuhan keperawatan. Jika sebaliknya maka hal ini sudah masuk ranah hukum privat dan hukum publik oleh karenanya diserahkan kepada proses hukum yang berlaku.

Menurut PPNI sebagai hal yang terpenting bagi baik dan tidaknya seorang perawat dalam menjalankan profesinya sebagai perawat adalah pada saat dia mengenyam pendidikan di Perguruan Tinggi. Sikap Kedisiplinan dan sifat jiwa kemanusiaan yang ditanamkan di perguruan tinggi akan sangat berguna bagi para perawat nantinya ketika berada di tengah masyarakat dan berinteraksi dengan masyarakat. Dan dalam pendidikan keperawatan lebih baik jika mengenalkan peraturan perundang-undangan terkait dengan keperawatan. Hal mana karena manfaat mempelajari hukum itu cukup banyak salah satunya dalam kehidupan sehati-hari kita sering menemukan hukum yang secara langsung dan tidak terkait dengan kehidupan kita. Pada dasarnya hukum itu perlu dipelajari oleh siapapun, tak pandang siapapun dan itu merupakan kewajiban bagi kita.

Hasil penelitian ini memberikan gambaran nyata berdasarkan hasil survey bahwa keberadaan perawat praktek di masyarakat pedesaan khususnya masih kurang, hal mana dikarenakan pemahaman 
Undang-Undang No.38 tahun 2014 tentang Keperawatan belum sepenuhnya dikuasai oleh perawat, padahal peraturan perundang-undangan tentang keperawatan itu dibuat dan disahkan salah satunya untuk mengatur tata cara kerja dan hubungan kerja antara perawat dan pasien sehingga tercipta hubungan yang harmonis antara perawat dan masyarakat yang menjadi pasien tersebut. UndangUndang No.38 tahun 2014 tentang Keperawatan memuat bagian penting terkait dengan hal keperawatan baik cara bekerja maupun eksistensnya di masyarakat.

Oleh karena itu rencana selanjutnya adalah memberikan pemahaman dan pembelajaran melalui sosialisasi terhadap Undang-Undang No.38 tahun 2014, dengan tujuan meningkatkan pemahaman dan pengertian Undang-Undang N.38 tahun 2014 tentang Keperawatan sehingga dapat meningkatkan kesadaran hukum yang nantinya menciptakan kemauan yang kuat bagi perawat untuk dapat lebih aktif lagi di masyarakat karena perawat menjadi mengerti dan paham bahwa adanya perlindungan hukum dari perangkat hukum.

\section{KESIMPULAN}

Berdasarkan hasil penelitian didapatkan kesimpulan sebagai berikut :

a. Perawat belum paham mengenai regulasi atau peraturan-peraturan dengan sejelas-jelasnya dari instansi yang terkait atau pun dari PPNI tentang pelaksanaan hak dan kewajiban perawat ketika berada di masyarakat. Dengan kata lain perawat merasa dirinya masih "kategori abu abu". Pengertian kategori abu-abu ini dimaksudkan adalah perawat masih ragu bilamana ikut andil secara aktif di masyarakat sebagai perawat praktek mandiri dalam upaya pelayanan kesehatan di masyarakat itu perawat apakah ada perlindungannya atau tidak.

b. bahwa masyarakat di pedesaan menganggap Perawat dan juga Bidan menjadi tempat tujuan untuk dapat memberikan pertolongan jika ada anggota masyarakat yang sakit dalam hal ini khususnya sakit gawat dan darurat. Berdasarkan Undang-Undang No.44 tahun 2009 tentang Rumah Sakit pada pasal 1 huruf 2 yang disebut sebagai gawat darurat ialah keadaan klinis pasien yang membutuhkan tindakan medis segera guna penyelamatan nyawa dan pencegahan kecacatan lebih lanjut. Darurat medis adalah suatu kondisi dalam pandangan penderita keluarga atau siapapun yang bertanggung jawab dalam membawa penderita ke rumah sakit memerlukan pelayanan medis segera.

c. Undang-Undang Keperawatan (UUK) merupakan dasar hukum praktek keperawatan. Isi Undang-Undang Keperawatan harus diketahui oleh profesi dan calon profesi (mahasiswa). Hal ini dikarenakan, tidak hanya profesi perawat yang membutuhkan Undang-Undang ini tetapi calon profesi perawat juga harus mengetahui isi dari Undang Undang Keperawatan agar di masa mendatang bisa menjadi perawat yang taat akan aturan serta menjalankan hak dan kewajibannya sebagai seorang perawat 


\section{DAFTAR PUSTAKA}

Arrie Budhiartie, Jurnal Universitas Jambi pertanggungjawaban hukum perawat dalam penyelenggaraan pelayanan kesehatan di rumah sakit,Vol 11 No.2 Desember 2009

Jawade Hafidz, Metode Penelitian Hukum, Semarang, FH Unissula, 2009.

Muchsin, Perlindungan dan Kepastian Hukum bagi Investor di Indonesia, Surakarta, disertasi S3 FH Universitas Sebelas Maret, 2003.

Peter Mahmud Marzuki, Pengantar Ilmu Hukum, Jakarta Kencana, 2008.

Philipus M. Hadjon, Perlindungan Hukum Bagi Rakyat Indonesia, Jakarta, Bina Ilmu, 1987.

Ronny Hanitijo Sumitro, Metodologi Penelitian Hukum dan Jurimetri, Jakarta,Ghalia, 1990

Satjipto Rahardjo, Sisi-sisi lain dari Hukum di Indonesia, Kompas Jakarta, 2003.

Setiono, Rule Of Law (Law Supremation), Surakarta, Magister Ilmu Hukum, Universitas Sebelas Maret, 2009

Soekijo Notoatmojo, Etika dan Hukum Kesehatan, Balai Pustaka, 2010. 